\title{
Non-Destructive Evaluation of Composite Helmets Using IR Thermography and Ultrasonic Excitation
}

\author{
Waldemar Świderski, Monika Pracht \\ Military Institute of Armament Technology, Wyszyńskiego 7 St., 05-220 Zielonka
}

\begin{abstract}
The paper presents selected results of non-destructive testing of composite helmets with deliberately introduced defects. Ultrasound pulsed infrared thermography was used for the tests. In order to determine the initial possibilities of this method, artificial defects made of Teflon featuring different area sizes and designed to simulate delamination were placed between layers of the aramid composite from which the helmet was made. The obtained results confirmed the effectiveness of the NDT method used in these tests.
\end{abstract}

Keywords: non-destructive testing, IR thermography, ultrasounds



\section{Introduction}

In recent years, composite materials have been used more and more frequently in lightweight ballistic armour designs. This is because advances in polymer chemistry have enabled production of materials capable of protecting against hits of small arms projectiles and other fragments. Usually woven (textile) materials combined with plastic are used, creating multi-layer composites from which personal ballistic armour (vests and helmets), armoured vehicles' panels and solid objects stationary facilities. This type of composite material is largely manufactured on the basis of highly resistant aramid and polyethylene fibres combined with phenolic and polyurethane resins as well as other flexible blends. These materials are characterized by being lightweight, corrosion-resistant, and easily mouldable which allows them to be adapted to surfaces they are to protect. Material layers can vary significantly in terms of their physical properties and because of this they are a difficult object of tests for many traditional non-destructive testing techniques. Defects that may appear in this type of multilayer composites are usually inaccuracies in bonding of composite layers and delamination also resulting from impact of fragments and projectiles.

One of the most effective methods of non-destructive testing in examination of fibre-reinforced composite materials is infrared thermography. Usually, methods of active thermography are used for non-destructive testing of composite materials [1-2]. As shown in many works [3-6], ultrasounds can be a particularly effective thermal stimulation source for this type of material.

Autor korespondujący:

Waldemar Świderski, waldemar.swiderski@wp.pl

\section{Artykuł recenzowany nadesłany 16.06.2021 r., przyjęty do druku 12.10.2021 r}

Figure 1 presents a diagram of the test setup for ultrasonic infrared thermography (on [7]).

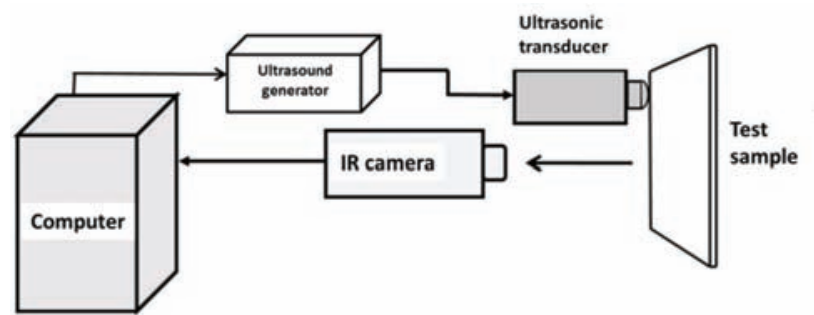

Fig. 1. Diagram of the test setup for ultrasonic infrared thermography Rys. 1. Schemat stanowiska termografii ultrasonograficznej

\section{Materials and Methods}

Thermographic and X-ray tests were carried out using a composite helmet with nine deliberately introduced defects in the form of Teflon.

The design of the splinter helmet i.e. the rigid outer shell of the helmet, not in contact with the user's head that defines the helmet shape and provides its essential function of ballistic protection, is made of composite materials.

Teflon defects in the shape of squares, inserted into the helmet shell, had a thickness of about $0.1 \mathrm{~mm}$ and a various surface areas of, respectively, 0.5 sq. cm. (D1, D2 and D3 defects), 1 sq. cm. (D4, D5, D6), and 1.5 sq. cm. (D7, D8, D9). Eight defects were placed at the height of $100 \mathrm{~mm}$ below the top of the helmet, and one defect at the height of $150 \mathrm{~mm}$ below the top.

The locations of the defects placed in the helmet are shown in Figure 2.

In the beginning tests of the helmet with deliberately introduced defects were carried out using the X-ray method. Then the helmet tests were performed using infrared ultrasonic thermography. The tests were carried out using different generator parameters, i.e. power up to $2 \mathrm{~kW}$, stimulation time up to approx. 130 seconds, recording time up to approx. 400 seconds and frequencies from $15 \mathrm{kHz}$ to $25 \mathrm{kHz}$. Infrared image sequences 


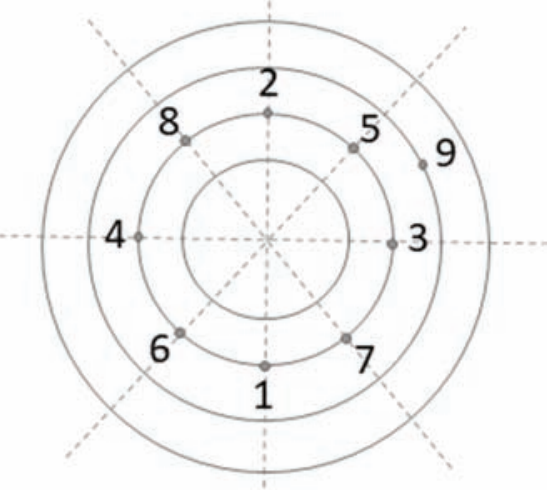

Fig. 2. Diagram of the defects locations in the helmet (Central circles designate the central point of the upper surface of the helmet) Rys. 2. Schemat lokalizacji defektów w hełmie (środek okręgów oznacza centralny punkt górnej powierzchni hełmu)

were recorded using the FLIR 7600 SC infrared camera (sensor type - InSb, spectral ranges 1.5-5.1 $\mu \mathrm{m}$, pixel resolution $640 \times$ 512 , pixel pitch $-15 \mu \mathrm{m}$, NETD $<20 \mathrm{mK}$, digital full frame rate $-100 \mathrm{~Hz}$ ), both in the heating and cooling phases. Pulse Phase Thermography [8] was used for the analysis of the thermograms obtained. The generator was placed in various locations and different ways of immobilizing (supporting) the helmet were used.

The experimental stand on which the helmet tests were carried out using infrared ultrasonic thermography is shown in Figure 3.

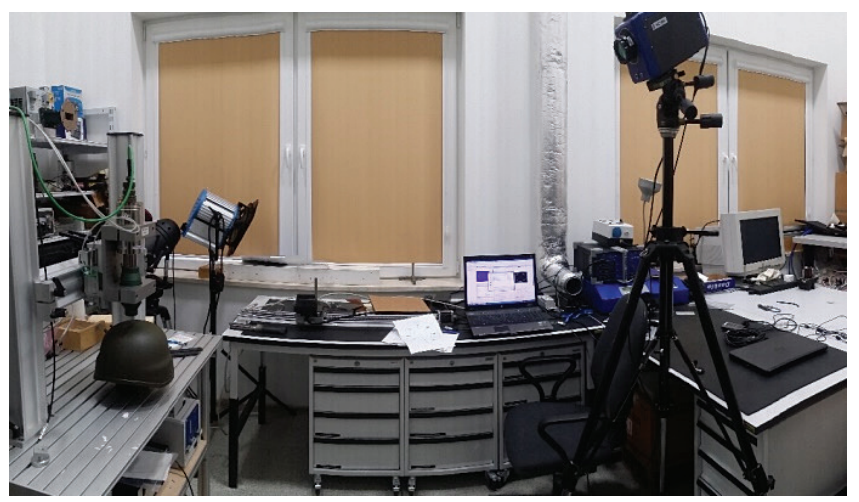

Fig. 3. Photo of the experimental stand used for the tests of the helmet

Rys. 3. Zdjęcie stanowiska doświadczalnego do testów hełmu

\section{Results and Discussion}

The results in the form of exographs of selected fragments of the helmet on which defects in the form of Teflon were detected, are shown in Figures 4 and 5. No defects were detected in the first stage of the X-ray analysis. Next, as a result of in-depth analyses (after a more detailed analysis of the imaging of defects in the form of Teflon inside flat samples), individual defects were detected. The defects are hardly visible in the $\mathrm{X}$-ray imaging and it is difficult to determine their location in the helmet; however, their shape can be seen.

The tests (Fig. 3) used the modular software package IR-NDT, which has been specially designed for non-destructive testing with active thermography by AT-Automation Technology GmbH [9]. Fourier transform is performed on the recorded signal using the Pulse Phase method. Thanks to this method, the phase spectrum of the temperature signal as a function of frequency is obtained. From the phase image sequence, you can select the image with the best representation of subsurface defects.
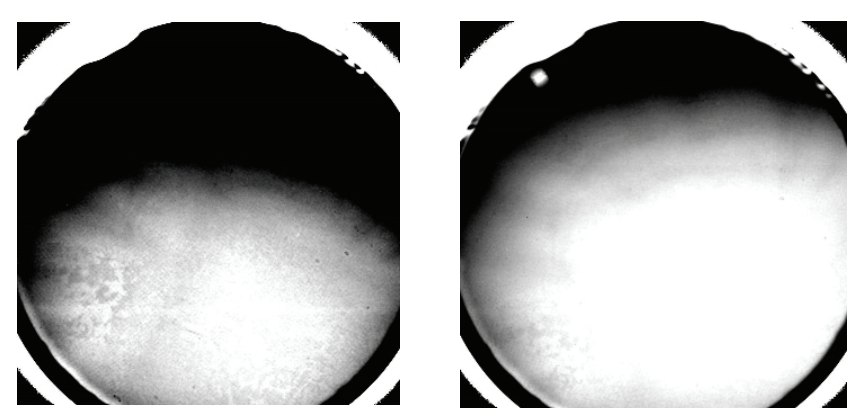

Fig. 4. X-ray images of a part of a composite helmet. View from inside on the left side of the helmet

Rys. 4. Obrazy rentgenowskie części hełmu kompozytowego, widok od wnętrza po lewej stronie hełmu

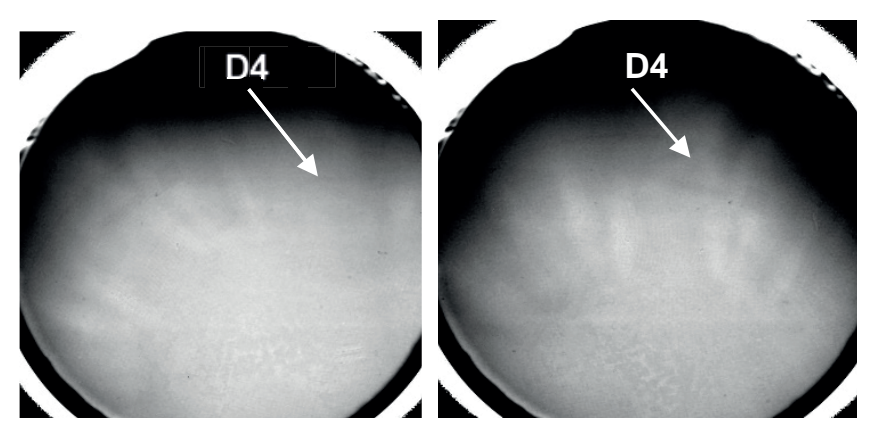

Fig. 5. X-ray images of a part of a composite helmet. The view from inside on the right side of the helmet

Rys. 5. Obrazy rentgenowskie części hełmu kompozytowego, widok od wnętrza po prawej stronie hełmu

Detection of a defect with the use of ultrasonic stimulation is influenced by: frequency, generator power and stimulation time of the ultrasonic wave, time of the cooling phase, depth of the defect location under the surface of the tested object and the distance between the defect and the place where the ultrasonic wave is generated. Taking all this into account, it is obvious that due to the different location of defects in the tested object, it is impossible to visualize all defects that can be detected on one thermogram.

Selected results of thermographic test of helmets, which were obtained at $24 \mathrm{kHz}$ frequency, are shown in Figures 6 and 7 .

Usually, thermographic tests are of the non-contact type; one of the exceptions is thermography using an ultrasonic source for thermal stimulation of the test object. For this reason, good mechanical contact between the surface of the test object and the transducer transmitting ultrasonic energy is very important. The shape of the composite helmet doesn't make it any easier. This contributes to generating a local field of increased temperature around the tip of the transducer on the surface of the tested object. This can be clearly seen in the thermogram,
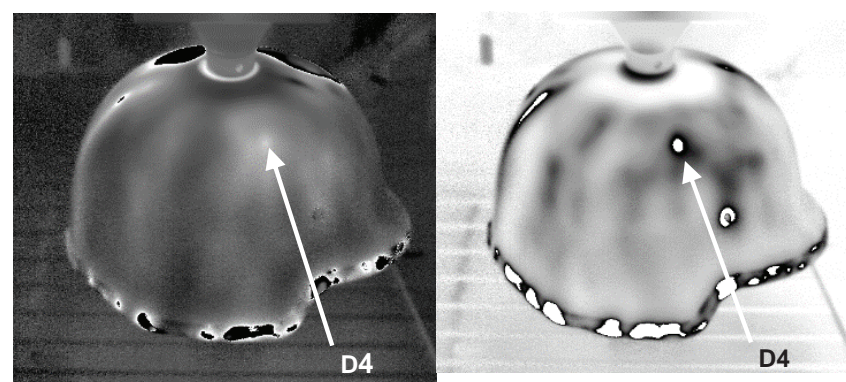

(b)

Fig. 6. Phase images of helmets obtained for various test parameters: (a) generator power $0.9 \mathrm{~kW}$, stimulation time $130 \mathrm{~s}$, recording time $200 \mathrm{~s}$; (b) generator power $1.05 \mathrm{~kW}$, stimulation time $130 \mathrm{~s}$, recording time $300 \mathrm{~s}$

Rys. 6. Obrazy fazowe hełmów uzyskane dla różnych parametrów badania: (a) moc generatora 0,9 kW, czas stymulacji $130 \mathrm{~s}$, czas rejestracji $200 \mathrm{~s}$; b) moc generatora $1,05 \mathrm{~kW}$, czas stymulacji $130 \mathrm{~s}$, czas rejestracji $300 \mathrm{~s}$ 


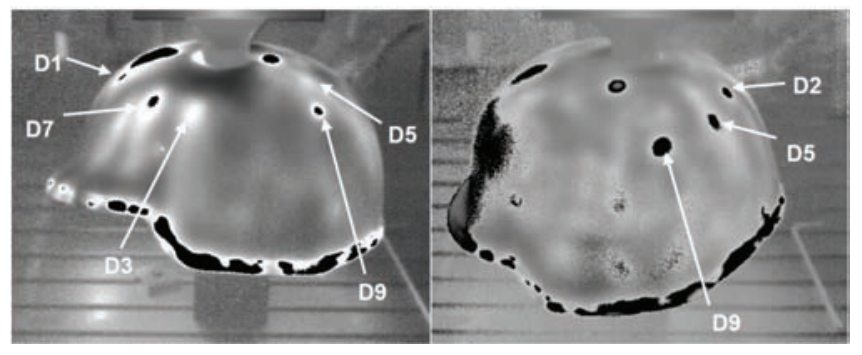

(a)

(b)

Fig. 7. Phase images of helmets obtained for various test parameters: (a) generator power $0.9 \mathrm{~kW}$, stimulation time $100 \mathrm{~s}$, recording time $240 \mathrm{~s}$; (b) generator power $0.9 \mathrm{~kW}$, stimulation time $80 \mathrm{~s}$, recording time $240 \mathrm{~s}$

Rys. 7. Obrazy fazowe hełmów uzyskane dla różnych parametrów badania: a) moc generatora $0,9 \mathrm{~kW}$, czas stymulacji $100 \mathrm{~s}$, czas rejestracji $240 \mathrm{~s}$; (b) moc generatora $0,9 \mathrm{~kW}$, czas stymulacji $80 \mathrm{~s}$, czas rejestracji $240 \mathrm{~s}$

Fig. 6b. The power of generated radiation and the time needed to generate it are important, because too much power and an excessively long time will cause the temperature to rise rapidly around the transducer tip. This, combined with pneumatic pressure of the transducer to the tested surface, may cause local damage.

Previous experiments have shown that the contact between the surface of the test object and the surface of the transducer tip can be improved by inserting a thin food grade aluminium foil (slightly crushed) between these surfaces. Attempts to use special gels did not bring any expected results. The gel dissolved very quickly and flown down the tested surface. Moreover, the gel caused hard-to-remove stains on the helmet surface.

Previously conducted numerical simulations, the results of which were published in [10], had indicated that the best results can be obtained at low ultrasound frequencies. This was confirmed in the experimental tests presented in this paper. When selecting the frequency, attention should be paid to avoid frequencies at which so-called standing wave is generated, because it results in black and white, often irregular stripes appearing on the thermogram (with the selected grey scale).

The tests presented in [11] shown that it is possible to improve the visualization of defects by using appropriate thermogram processing algorithms. ThermoFit ${ }^{\mathrm{TM}}$ Pro software developed by prof. V. Vavilov was used for thermogram analysis [12]. This software allows one to use several different algorithms of image processing for the analysis (Fourier analysis, differentiating transient signals, correlation technique, polynomial fitting, wavelet analysis, Principal Component Analysis and thermal tomography) with the option of changing their parameters. The best results obtained in $[13,14]$ were achieved by means of algorithms using the wavelet analysis and PCA (Principal Component Analysis). These results were obtained from tests of flat samples of the aramid composite. According to the analysis, the second and third principal components allow an increase of the good visibility of defects. In our further planned research we intend to apply these algorithms to testing of composite helmets.

The accuracy of the method used in these tests of helmets is indicated by the fact that the thermograms show the configuration of the arrangement of the aramid prepreg elements forming the shape of the helmet. Edges of triangular-shaped elements bonded in layers are visible as dark stripes on the thermograms.

\section{Conclusions}

The paper presents use of ultrasonic IR thermography for detection of deliberately introduced defects in composite helmets.

Analysis of the results obtained from both thermographic and $\mathrm{X}$-ray testing of helmets with deliberately introduced defects in the form of Teflon shown that phase image defects are more clearly visible and the area of their occurrence in the helmet is more easily identified. On the other hand, exographs show the shape of defects (which in turn is not visible on phasegrams).

The defects were best detected when the generator was placed at the point of the helmet top (determined in the central point of the upper surface) and the helmet was supported from inside with a metal cylinder (on which the helmet was supported, so that edges of the helmet did not touch the stand surface).

This work was supported by The National Centre for Research and Development (Project DOB-SZAFIR/02/A/001/01/2020).

\section{References}

1. Boritu A., Anghel V., Constantin N., Găvan M., Pascu A., Non-destructive inspection of composite structures using active IR-thermography methods. "UPB Scientific Bulletin, Series D: Mechanical Engineering", Vol. 73, No. 1, 2011, 71-84.

2. Sultan R., Guirguis S, Younes M., El-Soaly E., Active infrared thermography technique for the non-destructive testing of composite material, "International Journal of Mechanical Engineering and Robotics Research", Vol. 1, No.3, 2012, 131-142.

3. Wang Y.M., Wu Q., Experimental Detection of Composite Delamination Damage based on Ultrasonic Infrared Thermography, "International Journal of Engineering Transactions B: Applications", Vol. 27, No. 11, 2014, 1723-1730.

4. Pracht M., Swiderski W., Ultrasonic IR Thermography Detection of Defects in Multi-layered Aramide Composites, 19th World Conference on Non-Destructive Testing WCNDT, 2016.

5. Pracht M., Swiderski W., Detection of defects in composite helmets using ultrasonic IR thermography. Proc. of Integrity/ Reliability/Failure, 2018, 491-492.

6. Umara M.Z, Vavilov V., Abdullah H., Ariffin A.K., Quantitative study of local heat sources by Ultrasonic Infrared Thermography: An approach for estimating total energy released by low energy impact damage in $C / C$ composite. "Composites Part B: Engineering", Vol. 165, 2019, 167-173, DOI: 10.1016/j.compositesb.2018.11.124.

7. Hong Y., Miao P., Zhang Z., Zhang Shu-yi, Ji X., Installation and application of ultrasonic infrared thermography. "Acousting Science \& Techology", Vol. 25, No. 1, 2004, 77-80, DOI: 10.1250/ast.25.77.

8. Maldague X.P.V., Theory and Practice of Infrared Technology for Non-Destructive Testing. John Willey \& Son Inc. New York, 2001

9. IR-NDT, Software Manual. AT-Automation Technology GmbH, 2016

10. Świderski W., Pracht M., Vavilov V., Derusova D., Using ultrasonic IR thermography for detecting defects in military - oriented polyaramid materials, Proceedings of the $6^{\text {th }}$ International Conference on Mechanics and Materials in Design, 2015, 2219-2228.

11. Świderski W., Comparison of image analysis methods on the example of ultrasonic thermography of an aramid composite, Journal of KONES Powertrain and Transport, Vol. 26, No. 2, 2019, 145-150, DOI: 10.2478/kones-2019-0043.

12. ThermoFit Pro Operation Manual, Innovation Ltd., 2016

13. Swiderski W., Pracht M., Principal component analysis in non-destructive testing by an ultrasonic thermography method of multi-layered aramid composite, Proc. SPIE 11172, Fourteenth International Conference on Quality Control by Artificial Vision 111720D, 2019, DOI: 10.1117/12.2520854.

14. Swiderski W., Wavelet analysis for detection defects in light ballistic armours by ultrasonic infrared thermography method, Proc. of the $23^{\text {rd }}$ International Conference Transport Means, Part II, 2019, 621-624. 


\section{Nieniszcząca ocena hełmów kompozytowych z wykorzystaniem termografii w podczerwieni i wzbudzenia ultradźwiękowego}

Streszczenie: W pracy przedstawiono wybrane wyniki badań nieniszczących hełmów kompozytowych z celowo wprowadzonymi defektami. Do badań wykorzystano impulsową termografię w podczerwieni z ultradźwiękowym źródłem wzbudzenia cieplnego. W celu określenia wstępnych możliwości tej metody, pomiędzy warstwami kompozytu aramidowego, z którego wykonano hełm, umieszczono na różnych głębokościach pod powierzchnią sztuczne defekty wykonane z teflonu o różnej wielkości powierzchni. Te sztuczne defekty symulowały rozwarstwienia. Uzyskane wyniki potwierdziły skuteczność użytej metody NDT w tych badaniach.

Słowa kluczowe: badania nieniszczące, termografia w podczerwieni, ultradźwięki

\section{Prof. Waldemar Świderski}

waldemar.swiderski@wp.pl

ORCID: 0000-0003-4040-2197

A graduate of the Department of ElectroMechanical Arms of Military University of Technology (1978). Since 1980, an employee of Military Institute of Armament Technology, at present an associate professor. Research interests include non-destructive testing using infrared thermography and uses infrared technology in military applications. Author and co-author of more than 220 various scientific publications and 14 patents)

\section{Monika Pracht, PhD, Eng.}

prachtm@witu.mil.pl

ORCID: 0000-0002-6353-5147

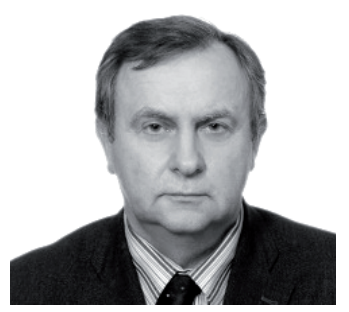

A graduate of the Department of Mechatronics of Military University of Technology (2007). Doctoral degree in technical sciences received in 2019 (construction and operation of machines). She completed postgraduate studies in Databases and data analysis in business at the Warsaw University of Technology (2012). Since 2007, she has been an employee of Military Institute of Armament Technology. Quality Manager of the Small Arms and Protection Materials Research Laboratory. 